Адиширинов К.Ф. История издания и литературно-культурное содержание газеты «Шекинский рабочий»

УДК 07(575.3)

DOI: $10.21779 / 2542-0313-2018-33-4-66-74$

\title{
К.Ф. Адищиринов
}

\section{История издания и литературно-культурное содержание газеты «Шекинский рабочий»}

Шекинский региональный научный центр; Азербайджанская Республика, AZ5500, г. Шеки, ул. Лютфали Абдуллаева, 24; kamil.adisirinov@mail.ru

Средства массовой информации являются важными факторами развития общества. На страницах газетных материалов отображается жизнь человечества, стремящегося в будущее.

В статье исследуется 70-летняя история газеты «Шекинский рабочий», впервые опубликованной в Шеки в 1921 году, с конкретным анализом социально-политических, литературно-культурных вопросов. Автор раскрывает факты из истории газеты, её редакторов и корреспондентов, а также её идеи о литературной критике и журналистике. На страницах газет, опубликованных в 1930 году, даётся высокая оценка шекинскому ашугскому фольклорному искусству несмотря на то, что оно было вне поля зрения азербайджанского фольклороведения советского периода. Фольклороведы свели к минимуму значение творчества ашуга Моллы Джумы, однако на страницах газет даны факты творчества 7 ашугов, принимавших участие во II съезде ашугов. In the development of the literary process in the city of Sheki in the 1920-1980 years, active has developed a literary Majlis of "Sabuhi". В развитии литературного процесса в г. Шеки в 19201980 годах активную деятельность развил литературный меджлис «Сабухи».

Статья актуальна как в национальном, так и в международном плане развития журналистских отношений. Газета издавалась до 1991 года.

Ключевые слова: литературное собрание, газета, съезд ашугов, произведения, культура, писатель, шекинские ашуги, газета «Шекинский рабочий», журналист, народное просвещение.

\section{Введение}

В статье исследуются история печати в Шеки в 1921-1991-е годы, история опубликования и литературно-культурное содержание газеты, которая сыграла важную роль в жизни города. Кроме того, на страницах газеты ашугское творчество находится в центре внимания. Исследователь газеты «Шекинский рабочий» также анализирует развитие художественной публицистики.

Одной из первых газет, выпущенных после победы Советской власти, стала газета «Шекинский рабочий». Её предшественниками были газетные листы «Кавказская коммуна», «Известия» («Ахбар»), «Молодой коммунист». С октяб-

66 Вестник Дагестанского государственного университета.

Серия 2. Гуманитарные науки. 2018. Том. 33. Вып. 4 
Адиширинов К.Ф. История издания и литературно-культурное содержание газеты «Шекинский рабочий»

ря 1921-го года вместо этих листов стали выпускаться газеты «Нухинский работник», «Нухинский рабочий», «Ленинское знамя», а затем «Шекинский рабочий».

Выдающийся журналист Махьяддин Аббасов, долгие годы руководивший редакцией газеты «Шекинский рабочий», в своей статье «Путь, пройденный нашей газетой», отразившей историю развития газеты, пишет, что до Апрельской социалистической революции в Азербайджане газета в Нухе не выпускалась. Вечером 28 апреля 1920-го года Нухинский революционный комитет издал указ о полномочиях Революционного комитета на типографию специального владельца в Нухе, национализировав её. В это время возникла большая необходимость в издании газеты. Исходя из этого, Революционный комитет стал выпускать газету под названием «Кавказская коммуна». Через некоторое время она стала издаваться под названием «Ежедневные известия». Наряду с этим выпускались специальные газеты: «Молодой труженик», «Молодой коммунист» и листы под названием «Лист просвещения». В 1921 году Нухинская партийная организация издала указ об объединении всех газет и листов.

С того времени газета стала выходить сначала под названием «Нухинский рабочий», а затем «Шекинский рабочий». В связи с финансовыми трудностями в 1925 году газета «Шекинский рабочий» была закрыта. В это время нухинские рабочие, чтобы продолжить издание своей газеты, оказывали ей финансовую помощь [1].

Сведения журналиста, поэта, прозаика, кандидата филологических наук Сабира Эфендиева об историческом развитии газеты «Кавказская коммуна», которая является предшественником газеты «Шекинский рабочий» и других печатных изданий, вызывают большой интерес. Исследователь в своих заметках даёт сведения о месте издания, о редакторе и о преемниках газеты. В связи с этим в его статье «Из истории шекинской печати» читаем, что первым редактором рабочей газеты в Шеки был Тофик Нуреддин.

В результате его упорного труда в 1920 году в Шеки начала издаваться газета «Кавказская коммуна» Азербайджанским отделом Русского телеграфного агентства. «Кавказская коммуна» - первая газета, печатавшаяся в Шекинской типографии. Основал ее Гасан Гаджиджелил оглы Мустафаев в 1909 году. Первый номер газеты не был сохранён, поэтому точных сведений о дате его издания нет. Имевшиеся на руках номера свидетельствуют о том, что газета выходила три, а иногда четыре раза в неделю. До 13 октября 1920 года были напечатаны 58 номеров. Опираясь на имеющиеся сведения, можно предположить, что газета стала печататься с мая 1920 года. После того, как типография попала в руки уездного Революционного комитета, ею стали руководить Абдулрза Гусейнов и Шакир Эфендиев. «Ежедневные известия» стали печататься с апреля 1921 года как орган Шекинского отдела просвещения и союза органов просвещения. Газета издавалась до февраля 1922 года, то есть до первого съезда Шекинского и Закатальского пунктов профессионального союза. Было выпущено до ста номеров газеты. 
Адиширинов К.Ф. История издания и литературно-культурное содержание газеты «Шекинский рабочий»

В 1924 году начал печататься общественно-литературный журнал деятелей просвещения «Билги» («Знание»). Было выпущено всего три номера. Исследователь допускает ошибку по вопросу количества, потому что в данный момент в Институте рукописей сохранены четыре номера журнала. Третий и четвертый номера журнала были выпушены под одним переплётом, поэтому, наверное, это не привлекло внимание исследователя. Последний номер журнала был выпущен в апреле, когда Коммунистическая партия провозгласила лозунг культурной революции, и появилась необходимость печатания в газете «Шекинский рабочий» приложения «Просвещение и культурный лист» [8].

В сентябре 1921 года была опубликована газета «Молодой труженик» недельный орган Союза азербайджанской коммунистической молодёжи Шекинского уездного комитета. Газета печаталась с октября 1923 года под названием «Молодой коммунист» два раза в месяц тиражом в 1300 экземпляров. Выпускалась под редакцией Гамида Рустамбейли. Вначале газетой «Шекинский рабочий», которая печаталась с 25 октября 1921 года, стали руководить члены уездного Революционного комитета Абид Эфендиев и Гулам Ахундов. В 70-м году газета стала трибуной шелководов, всех тружеников уезда, старалась выполнять функции помощника партийной организации. Перелистывая пожелтевшие страницы этой газеты, можно увидеть зеркальное отражение борьбы и побед. В Шеки (Закатальской зоне) газета «Шекинский рабочий» стала настоящей летописью развития народного хозяйства и культуры, сыграла роль дневника.

С первого издания газета объясняла цели Советской власти и ленинских идей, призывала тружеников восстановить хозяйство, увеличить производство шёлка, открыть школы, бороться с необразованностью. Газета подробно передавала обращения Н. Нариманова, М. Фрунзе, А.Н. Караева, Г. Мусабекова, М. Кулиева, выступавших в Шеки.

В 1921-1924-х годах статьи, посвящённые В.И. Ленину, привлекают внимание своим множеством. В феврале 1922 г. в Москве был проведён Всероссийский съезд работников швейной промышленности. Портной Абдулгусейн Зейналов был делегатом этого съезда. В одном из номеров газеты он с радостью рассказывал своим читателям о том, что ему посчастливилось увидеть Ленина, слушать его речь на съезде. Мастер по текелдузу Джаббар Ализаде шёлковыми нитками создал портрет Ленина. Газета нашла это произведение и напечатала его фотоснимок.

На страницах газет были прославлены представители Доду и Кишлага, так называемых территорий Шеки, по инициативе которых были построены школы, организованы курсы по изучению нового алфавита, освещалось активное участие в общественной жизни женщин, первыми сбросивших чадру. Ведя активную работу в школах, в области культуры и среди женщин, Гюлара Кёйлю кызы (впоследствии она была редактором журнала «Женщина Востока»), Н. Ахмедова, Б. Гашымзаде, 3. Имамвердиева умело пользовались силой слова в печати. Следы большой работы, проделанной Р. Эфендиевым, С. Гусейновым, А. Махмудовым в развитии народного образования и подготовке специалистов из бедных крестьянских детей, остались на газетных столбцах. В Шеки любители ли- 
Адиширинов К.Ф. История издания и литературно-культурное содержание газеты «Шекинский рабочий»

тературы и молодые писатели объединялись вокруг газеты и печатали свои произведения. Сначала на страницах газет, а затем в небольшом по объёму журнале под названием «Гызыл гелемлер» («Золотые перья») печатались рассказы и стихи С. Рахмана, Н. Эфендиева, Р. Эфендиева, А. Демирчизаде, О. Джумазаде, М. Ахундова. Традиционно в редакции до 1991 года действовал кружок литературных силовых объединений, который вёл большую работу в объективном освещении литературно-культурной жизни.

Интересные темы приходили в газету из жизни, и усилиями корреспондентов и авторов доводились до читателей. В газете «Шекинский рабочий» наряду с ветеранами - корреспондентами (Г. Лачынзаде, В. Мустафаевым, Х. Саламовым, И. Билаловым, М. Сулеймановым) было более 200 молодых корреспондентов, которые писали о развитии, об успехах, о передовой практике, смело критиковали недостатки. В 1930 году как широкое культурное событие был отмечен юбилей тысячного номера газеты в Закавказье, а в 1931 - десятилетие газеты.

Газета «Шекинский рабочий» была первой школой для ряда известных учёных, общественных деятелей и журналистов. Редактор многотиражной газеты «Мубариз» («Боец»), ранее выходившей в Шекинском МТС (машиннотракторная станция), Сабит Рахман сотрудничали с газетой «Шекинский рабочий», где и издал первые рассказы. Когда профессор, член-корреспондент Академии наук АзССР Абдулаззал Демирчизаде был заведующим отделом редакции, свои стихи, поэмы и театральные рецензии он также печатал на страницах этой газеты [7].

Одним из борцов за газету, подобно Фархаду с киркой в руках, был Мамедсани Мамедов. Большая заслуга его как редактора газеты в формировании ряда журналистов, которых в 30-е годы коснулись воспитании тяжёлые трагедии. Много интересных сведений получаем о том, как преподаватель Азербайджанского педагогического института (АПИ) им. В.И. Ленина (ныне АГПУ) Муса Гаджизаде, когда работал учителем в Шеки, помогал молодым литераторам. В 1934-1936 годах редакторами газеты «Шекинский рабочий» были бывший руководитель кафедры журналистики Азербайджанского государственного университета им. С.М. Кирова Гасан Шахвердиев и член-корреспондент Академии наук республики Зульфели Ибрагимов.

Не оставаясь равнодушной к литературному наследию, газета рассказывала своим читателям о таких выдающихся поэтах тоговремени, как Исмаил бек Накам, Г. Гази, Н. Махзун, ашуг Молла Джума. Учитель литературы в средней школе Мамедемин Салимов нашёл произведение азербайджанского поэта Хатибоглы «Фарахнаме». Газета первая в республике сообщила об этом и напечатала отрывки из «Фарахнаме» [10-13]. С интересом со стороны читателей были встречены статьи «Самед Вургун в Шеки», «Юбилейные торжества на родине М.Ф. Ахундова», «Фотоснимок ашуга Молла Джума», «Александр Фадеев и Самед Вургун в Нухе».

Выпуски газеты 1930-х годов вызывают большой интерес к ашугскому творчеству. Исследования показывают, что в эти годы в Шеки и его окрестных сёлах было развито ашугское творчество, на этих территориях жили и творили 
Адиширинов К.Ф. История издания и литературно-культурное содержание газеты «Шекинский рабочий»

народные ашуги. Творчество ашугов Паши из Доду, Керима из Кишлага, Мугума из Джафарабада, Ахмеда и Мухаммеда из Баш Лаисгы, Ахмеда из Ашагы Лаисгы, Шамиля из Дашбулага, Гюльахмеда из Шина, Ахмеда из Шабалыда, Мусы из Биледжика осталось на страницах газеты.

Как известно, после 20-х годов XX в. ашугская литература, как и другие области устного словесного творчества, стала систематически развиваться, и в этой сферы были проведены широкомасштабные мероприятия. В марте 1938 года на II съезде Азербайджанских ашугов наряду с выходцами из других областей участвовали и нухинские ашуги. Но, к сожалению, в исследованиях учёныхфольклористов не было указано место деятельности нухинских ашугов. По этому поводу известный музыковед, учёный-фольклорист, профессор кафедры этнокультурологии Санкт-Петербургского государственного института им. А.И. Герцена Фаик Челеби писал, что второй половине XX века исследователи ашугского творчества не смотрели в сторону Шеки и потому стали беспомощными перед вопросами и вели тайные и беспочвенные разговоры. То есть Шеки стал описываться как край любивших мугам и газели, но равнодушных к ашугскому творчеству купцов и аристократов [3, т. 8, с. 23].

Так как учёные, исследовавшие ашугскую литературу, не принимали фразу «ашугская среда в Шеки», эта тема осталась в стороне исследования. Газета «Нухинский работник» (под такимзаголовком издавалась газета «Шекинский рабочий» в 30-е годы) в своих выпусках за 10 и 12 января 1938 года [4] напечатала извещение (анонс) с именами ашугов и писателей, которые будут присутствовать на совещании Нухинского городского совета в связи с участием шекинских ашугов на II съезде азербайджанских ашугов. 13 января 1938 года в 12 часов дня состоялось совещание нухинских ашугов и нухинских советских писателей в Нухинском городском совете.

Статья Мамедии Сулейманлы «Конференция нухинских ашугов» [15] в номере газеты «Нухинский работник» от 10 марта 1938 года создаёт у нас полное представление о конференции всех нухинских ашугов вместе с советскими писателями и литераторами, которая проводилась 4 марта того же года в доме партийного просвещения в связи с подготовкой азербайджанских ашугов к республиканскому съезду. После доклада А. Фаруга, выступили и другие гости конференции, которые говорили о том, что в районе много ашугов, но с ними не ведётся работа. Ни уполномоченный по делам искусств, ни писатели нухинского совета, ни учителя литературы - никто не обращает внимания на развитие творчества ашугов, на повышение политических и технических знаний. Поэтому многие ашуги до сих пор не образованны [15].

Сотрудник редакции газеты «Нухинский работник» Джамал Гадирли из села Охуд выступил с более острой позицией, обвиняя прошлое руководство города в равнодушном отношении к развитию ашугского творчества в Нухе. По его мнению, народные враги, некогда сидевшие в Городском партийном Совете, Чуварлинский, Солтанов и бывший председатель Городского совета создавали беспорядок в области искусства. Особенно к ашугам было непростимое бюрократическое отношение. Они часто не вызывали совещания ашугов, не вели с 
Адиширинов К.Ф. История издания и литературно-культурное содержание газеты «Шекинский рабочий»

ними широкую работу. Ещё один сподвижник Чуварлинского Алешраф Исмаилов собирал записи ашугов, но не публиковал их [15]. В заключении статьи читаем о нухинских делегатах, избранных на второй съезд республиканских ашугов: «После выступлений начались выборы азербайджанских ашугов на республиканский съезд и товарищи единогласно избрали делегатами ашуга Шамиля, ашуга Ахмеда из Лаисгы, ашуга Пашу, ашуга Ахмеда из Шабалыда, ашуга Мугуму из Джафарабада» [15].

Ашуги должны делать «полезную работу» - восхвалять Ленина, партию, воспевать торжество коммунизма. Отношение политической идеологии руководства к ашугскому творчеству показало себя на собрании, проводимом 3 февраля 1938 г. составом Управления нухинского филиала Союза азербайджанских советских писателей, где наряду с другими мероприятиями шёл разговор и «о прикреплении к ашугам» советских писателей. Под влиянием этой идеологической власти в 30-х годах на страницах газеты «Нухинский работник» появилось множество стихов ашугов Ахмеда (Баш Лаисгы), Мусы (Биледжик), Мугумы (Джафарабад), Шамиля (Дашбулаг), Ширина и других мастеров о Ленине, Сталине, Ворошилове, социализме, коммунистическом пути, Советской стране, Красной Армии. Учитывая научную ценность стихов, было бы уместно обратить внимание на ашугскую среду в Шеки.

Выдающийся ученый-фольклорист, академик Азад Набиев, обсуждая дастаны о беглецах, пишет: «...Другой вариант дастана (имеется в виду дастан «Гачаг Керем» - «Беглец Керем») «Керем хан Шартиб» был записан членами фольклорной экспедиции, отправившейся в Нухинский район (Шеки) в 1937 году под руководством народного артиста СССР Бюлбюля. Дастан рассказывал ашуг Ширин Исмаилов» [9, Т. 1, с. 683-684]. Фотография 7 человек с сазами в руках и одного человека с балабаном в газете «Нухинский работник» 2 октября 1938 года доказывает наше предположение, что ашугское творчество характерно для литературной среды Нухи. Внизу фотографии написано: «Ашуги Нухинского района готовятся к XXI годовщине Великого Октября. На фотографии ашуги района» [6].

Как мы видим из коротких пояснений к данным примечаниям, газета не избегает сообщений об ашугском творчестве в Шеки. В выпусках газеты «Шекинский рабочий» последующих годов уделялось место ашугскому творчеству, столбцы газеты украшали стихи ашугов Гаджибалы, Исмаила, Мусы, Сакита.

Во время Великой Отечественной войны газета тоже была «бойцом», держа как знамя лозунг «Всё для победы», вдохновляла тружеников тыла, звала на помощь фронту. В газете были напечатаны статьи о наших земляках С. Эльдарове, Н. Османове, Н. Акберове, Г. Ильясове, М. Сулейманове, Ш. Гусейнове, о таких партизанах, как Ахмедия Джабраилов из села Охуд (участвовал в движении сопротивления Франции) и Нуру Абдуллаев, которые героически воевали в годы войны против фашизма.

Большое внимание уделялось теме военно-патриотического воспитания молодёжи.

Вестник Дагестанского государственного университета.

Серия 2. Гуманитарные науки. 2018. Том. 33. Вып. 4 
Адиширинов К.Ф. История издания и литературно-культурное содержание газеты «Шекинский рабочий»

Секретарь ЦК КП Азербайджана Назим Гаджиев в 1942-1943 годах был литературным работником, деканом факультета журналистики. Журналист, профессор Ширмамед Гусейнов в 1944 году был литературным работником. Руководитель действующего в Шеки двухлетнего института учителей, кандидат филологических наук Расул Расуллу тоже редактировал газету.

Благодаря деятельности Махьяддина Аббасова, назначенного на должность заведующего редакцией газеты «Нухинский рабочий» в 1944-1946 годах, идейно-политическая роль газеты среди масс усилилась. С 1946 года с назначением его главным редактором газета превратилась в настоящую трибуну, с которой до народа доводились статьи, выражающие взгляды творческих людей. Литературный меджлис «Сабухи», действующий на базе редакции газеты, ещё более расширил свою активность благодаря усилию и поддержке М. Аббасова. Любовь к нации не осталась не замеченной первым секретарем Компартии Азербайджана Гейдаром Алиевым, который в 1971 году удостоил его за плодотворную деятельность почётным званием «Заслуженный работник культуры республики». В 1974 году после смерти М. Аббасова редактором был назначен претворял в жизнь Анвер Микаилзаде, а затем - талантливый публицист Низами Набиев. Во время его работы в редакции литературный кружок «Сабухи» продолжал свою деятельность.

В разные годы в литературном кружке «Сабухи», который действовал на базе редакции газеты «Шекинский рабочий», трудились такие талантливые люди, как Лютвели Гасанов, Махяддин Аббасов, Мамедия Сулейманов, Ягуб Махир, Нурпаша Гумбетов, Мамед Челебиев, братья Мухтар и Валех Гияси, Сурагат Гурбани, Анвер Мирзаоглы, Елмир Шейхзаде, Юсиф Исмаилов, Алешреф Шаяан, Тофик, Гаффаров, Ровзат, Гуртулуш Сулейманлы, Веусал Чаркез, Гусейн Расулов, Тельман Гамидли, Рамиз Орсер, Вагиф Аслан, Маис Селим, Алескер Саламов, Юсиф Шукурлю, Ахмед Зейзидли, Габиллах Камиль и др. Сложившаяся политическая обстановка в республике в 1991 году и застой в деятельности газеты отразились и на деятельности литературного кружка «Сабухи». Но усилиями интеллигенции, любящей литературу, меджлис продолжил свою деятельность на базе Центральной библиотеки имени И.С. Накама ЦБС Шеки.

Исследование материалов доказывает, что газета «Шекинский рабочий» на своих страницах благодаря редакторам и корреспондентам отразила все особенности национальной журналистики.

\section{Литература}

1. Аббасов M. Путь, пройденный нашей газетой // Газета «Нухинский рабочий». - Нуха, 1946, 23 октября.

2. Антология азербайджанского фольклора. Шекинский фольклор: в 6 т. Баку: Нурлан, 2006. - Т. 2. - 532 с.

3. Антология азербайджанского фольклора. Шекинский фольклор: в 8 т. Баку: Нурлан, 2009. - Т. 8. - 579 с.

4. Газета «Нухинский работник». - Нуха, 1938, 10-12-13 января.

72

Вестник Дагестанского государственного университета.

Серия 2. Гуманитарные науки. 2018. Том. 33. Вып. 4 
Адиширинов К.Ф. История издания и литературно-культурное содержание газеты «Шекинский рабочий»

5. Газета «Нухинский работник». - Нуха, 1938, 6 февраля.

6. Газета «Нухинский работник». - Нуха, 1938, 2 октября.

7. Газета «Нухинский работник». - Нуха, 1936, 23 августа.

8. Эфендиев С.Т. Из истории Шекинской печати // Газета «Шекинский рабочий», Шеки, 1973, 22 марта.

9. История азербайджанской литературы: в 10 т. - Баку: Наука, 2004. - Т. 1. $-760 \mathrm{c}$.

10. Салимов M. «Fәrəhnamə» // Газета «Шекинский рабочий», Шеки, 1969, 11-13 декабря.

11. Салимов M. «Fәrəhnamə» - древний художественный памятник // Газета «Шекинский рабочий». - Шеки, 1971, 2 сентября.

12. Салимов М. Хатибоглу о слове // Газета «Шекинский рабочий». Шеки, 1971, 7-9 января.

13. Салимов М. Отличительные части из сокровищницы Мухаммада Хатибоглу // Газета «Шекинский рабочий». - Шеки, 1973, 24 апреля.

14. Салимов М. Кто такой Хатибоглу? // Газета «Шекинский рабочий». Шеки, 1973, 23-25 января.

15. Сулейманль M. Конференция Нухинских ашугов // Газета «Нухинский работник». - Нуха, 1938, 10 марта.

\section{References}

1. Abbasov M. The Way, Going to the Newspaper // "Nukhinsky woker" gas., Nuha, 1946, 23 October.

2. Anthology of the Azerbaijani Folklore: Sheki folklore. VI book. B.: Nurlan, 2006, V. 2. 532 p.

3. Anthology of the Azerbaijani Folklore: Sheki folklore. VIII book. B.: Nurlan, 2009, V. 8. 579 p.

4. The newspaper "Nukhinsky woker", Nuha, 1938, 10-12-13 January.

5. The newspaper "Nukhinsky worker", Nuha, 1938, 6 February.

6. The newspaper "Nukhinsky worker", Nuha, 1938, 2 October.

7. The newspaper "Nukhinsky worker", Nuha, 1936, 23 August.

8. Efendiyev S.T. From the history of the Shekin print // "Sheki worker", gas. Sheki, 1973, 22nd March.

9. The history of azerbaijan literatura: in 10 volumes. B.: Science, 2004, V. 1. $760 \mathrm{pp}$.

10. Selimov M. "Honorable" // "Sheki worker" newspaper, Sheki, 1969, 1113 December.

11. Selimov M. "Honorable" is a monument of ancient art. "Sheki worker" newspaper, Sheki, 1971, 2-7-9 September.

12. Selimov M. Khatiboghlu spoke about the word. "Sheki worker" newspaper, Sheki, 1971, 7-9 January.

13. Selimov M. Distinctive fragments from M. Khatiboglu's wisdom treasure. "Sheki Worker" newspaper, Sheki, 1973, 24 April.

14. Selimov M. Who is M. Khatiboglu? "Sheki worker", newspaper, Sheki, 1973, 23-25 January. 
Адиширинов К.Ф. История издания и литературно-культурное содержание газеты «Шекинский рабочий»

15. Suleimanly $M$. Conference of Nukh ashugs // Newspaper "Nukhinsky worker”, Nuha. 1938, March 10.

Поступила в редакиию 10 ноября 2018 г.

UDC 07(575.3)

DOI: $10.21779 / 2542-0313-2018-33-3-66-74$

\section{History of publication and literary and cultural content of the newspaper «Sheki fehlasi»}

\section{K.F. Adishirinov}

The Shekinsky Regional Center of Science; Azerbaijan Republic, AZ5500, Sheki, Lutfali Abdullayev st., 24; kamil.adisirinov@mail.ru

This is an indisputable fact that press is one of the means providing development of the society. On the pages of newspaper materials shows the life of humanity, striving for the future. The article examines the 70-year history of the newspaper «Sheki fahlasi», first published in Sheki in 1921, with a specific analysis of socio-political, literary and cultural issues. The author reveals facts from the history of the newspaper, its editors and correspondents, as well as its ideas about literary criticism and journalism. The newspapers published in 1930 highly appreciate the Sheki ashug folklore art despite the fact that it was out of the field of view of Azerbaijani folklore studies of the Soviet period. The folk researchers enlarge the importance of ashugs in Sheki, by referring to some creative samples of ashugs that remained in different pages of newspaper, as the specialists in folklore limited this Mola Juma's creativity. Even the participation of 7 ashugs from this region in the $2^{\text {nd }}$ republican ashugs congress in 1938 can be estimated as a new fact for Azerbaijan folklore studies. In the development of the literary process in the city of Sheki in the 1920-1980 years, a literary majlis of "Sabuhi" has developed an activeity.

The article is relevant both nationally and internationally in the development of journalistic relations. The newspaper was published until 1991.

Keywords: literary meetings, newspapers, congresses, publishing, culture, writers, Sheki discourses, newspapers "Shekinsky rabochiy», journalist, public education.

Received 10 November, 2018 